\title{
Supply Chain 4.0: the impact of supply chain digitalization and integration on firm performance
}

\author{
Kam Pui Liu ${ }^{1} \cdot$ Weisheng Chiu ${ }^{1}$ (D) \\ Received: 9 October 2021 / Accepted: 9 October 2021 /Published online: 10 November 2021 \\ (C) The Author(s), under exclusive licence to Springer Nature B.V. 2021
}

\begin{abstract}
The purpose of this study is to propose a research model to investigate the relationships between supply chain digitalization, supply chain integration, and firm performance. In particular, the mediating effect of supply chain integration and the moderating effect of supply chain digitalization in the research model are examined. An online survey is administered to Chinese employees $(N=264)$ working in the supply chain industry. Data are analyzed by the partial least squares structural equation modeling (PLS-SEM) using the SmartPLS 3.0. The findings of this study reveal that both digitalization and supply chain integration have a positive influence on firm performance. Moreover, supply chain integration partially mediates the relationship between supply chain digitalization and firm performance. Meanwhile, supply chain digitalization positively moderates the relationship between supply chain integration and firm performance. These findings address the research gap in the extant literature and provide practical implications in ethical supply chain management. In particular, this study reveals that supply chain digitalization can drive a higher level of ethical supply chain in the perspective of supply chain visibility and efficiency in operations.
\end{abstract}

Keywords Supply chain · Digitalization · Integration · Firm performance

\section{Introduction}

Supply Chain 4.0 can be considered the application of the Industry 4.0 concept in the context of the supply chain (Frederico et al., 2019). Industry 4.0, the fourth industrial revolution, is a phenomenon pertaining to digitalization and automation in industries

Kam Pui Liu

kpliu@hkmu.edu.hk

$\triangle$ Weisheng Chiu

chiuws@hkmu.edu.hk

1 Lee Shau Kee School of Business and Administration, Hong Kong Metropolitan University,

Ho Man Tin, Kowloon, Hong Kong 
(Kolberg et al., 2017) have led to many new ethical challenges in relation to ethical technology policies to be integrated to meet both ethical and financial goals. During the revolution, most of the organizations seems to struggle in transforming the visionary ideas to a missionary level of developing the ethics and sustainability in supply chain (Erol et al., 2016; Luthra \& Mangla, 2018). Both researchers and practitioners have expressed an interest in Industry 4.0 as one of the most emergent topics, as the traditional business models based predominantly on physical activities are being disrupted and shifting toward digitalization in recent years (Queiroz Maciel et al., 2019).

Without exception, digitalization has been the buzzword in the shipping and freight industry in the past decade. The influence and coverage of digitalization in the industry are steadily increasing (Manaadiar, 2020). Digitalization in the logistics and supply chain market is anticipated to grow at a computed annual growth rate (CAGR) of $8.5 \%$ from 2020 to 2027; the market was valued at US\$11.7 billion in 2019, and it is projected to reach US\$23.6 billion in 2020 (NASDAQ, 2020). Digitalization in the supply chain covers the application of digital technologies to plan and execute transactions, communications, and actions (Sanders \& Swink, 2020). Nearly 90\% of companies believe that digitalization will provide a competitive advantage in the supply chain in the next 5 years; however, most firms (73\%) are perceived to be highly unclear about what "digitizing" the supply chain signifies (SupplyChainDigest, 2016). Companies that are unprepared to capture these digital and technological advancements are likely to be left behind and eventually go out of business (Saxena, 2016).

Global supply chains are viewed as strategic assets, capabilities, and sources of competitive advantage (Min et al., 2019). Supply chains are assessed with respect to value; the integration of the supply chain has been accepted as fundamental to the success of a firm (Huo et al., 2014). Supply chain integration is defined as the extent to which a firm strategically collaborates with its supply chain members and collaboratively administers intra-organizational and inter-organizational processes (Flynn et al., 2010). Previous studies on the supply chain have generally suggested that supply chain integration may positively relate to firm performances (Frohlich \& Westbrook, 2001; Zhao et al., 2013). Moreover, digital technologies are believed to enable the integration across the various functions of a firm (e.g., material management, planning, and scheduling), ensuring that teams move forward in unison toward common goals (Gautr, 2020).

However, the issue of how digitalization is related to supply chain integration for improved firm performance is still unclear. Although the literature on supply chain digitalization and supply chain integration has generally indicated that these processes support and benefit firms (Björkdahl, 2020; Frohlich \& Westbrook, 2001; Gimenez, 2006; Lusch et al., 2010), empirical evidence and a research model demonstrating the relationship between digitalization and supply chain integration are lacking. Tian et al. (2019) have echoed this perspective in their ASEAN study, indicating the lack of empirical research about the extent to which the digitalization of the supply chain is implemented. Moreover, in their systematic review, Büyüközkan and Göçer (2018) have argued that little research has focused on the role of digitalization in supply chain management within the extant literature, and they have suggested the need for further studies exploring the impact of digitalization on the supply chain (Abdirad \& Krishnan, 2020). 
Accordingly, the purpose of this study is to empirically examine the relationships between digitalization, supply chain integration, and firm performance by proposing a research model based on the literature review to fill the knowledge gap in this realm. In particular, the mediating effect of supply chain integration and the moderating effect of supply chain digitalization in the research model are evaluated.

\section{Literature review and hypothesis development}

\section{Supply chain digitalization}

According to Legner et al. (2017), digitalization refers to the process associated with converting analog signals into a digital model and the impact of these technologies caused by adoption and operation. Digitalization has started to gain considerable attention from organizations all over the world, as it brings superior benefits to a wide range of companies. Digitalization in the supply chain enables the maximal use of digital technologies to plan and execute transactions, communications, and actions (Sanders \& Swink, 2020). Those digital technologies in the supply chain generally include big data analytics (BDA), advanced manufacturing technologies with sensors, decentralized agent-driven control, advanced robotics, augmented reality, advanced tracking and tracing technologies, and additive manufacturing/3D printing (Ivanov et al., 2019). For example, additive manufacturing/3D printing leads to the possibility of producing modules, components, and even end products in one place, and essentially in any place in the supply chain (Khajavi et al., 2014; Li et al., 2017). This process certainly affects the supply chain design; for example, a UPS and SAP joint technology allows UPS to manufacture items by directly using 3D printing at the distribution centers (UPS, 2018). These applications of digital technologies increase the speed, efficiency, and resilience of the supply chain. Resilience360 at DHL allows comprehensive disruption risk management by mapping the supply chain end-to-end, building risk profiles, and identifying critical hotspots to initiate mitigation activities and generate near-real-time alerts about incidents that could disrupt the supply chain (DHL, 2018).

\section{Supply chain integration}

Supply chain integration is generally classified into external and internal integration (Flynn et al., 2010; Frohlich \& Westbrook, 2001; Germain \& Iyer, 2006; Leuschner et al., 2013). External integration refers to the integration of the logistics activities of a firm with its customers and suppliers across boundaries (Stock et al., 1998). In internal integration, the departments and functions within a manufacturer are recognized as part of an integrated process; by contrast, the importance of establishing close, interactive relationships with customers and suppliers is acknowledged in external integration (Flynn et al., 2010). Internal integration pertains to the degree to which a firm can structure its organizational practices, procedures, and behaviors into collaborative, synchronized, and manageable processes to fulfill customer 
requirements (Cespedes, 1996; Kahn \& Mentzer, 1996). From the logistics and supply chain perspective, internal integration refers to the coordination, collaboration, and integration of logistics with other functional areas (Stock et al., 1998).

More studies have recently demonstrated internal integration as the pre-condition for external integration (Errassafi et al., 2019; Zhao et al., 2011). Some studies have only focused on internal integration, but not on external integration (Swink \& Nair, 2007; Swink \& Song, 2007), underscoring the importance of internal integration. For example, in a study on the Spanish food industry, Gimenez (2006) has shown that the highest levels of external integration are achieved by firms that have already reached the highest levels of internal integration between logistics, production, and marketing. Germain and Iyer's (2006) study on more than 2000 members of the Council of Supply Chain Management Professionals (CSCMP) has indicated that a firm's performance will be limited with external integration only when no internal integration occurs. Hence, both conceptual arguments and empirical evidence evidently support internal integration as the enabler for external customer and supplier integration, suggesting that an effective approach for enhancing external integration is to pursue internal integration (Errassafi et al., 2019; Zhao et al., 2011). In other words, supply chain integration could not be successful in the absence of a high level of internal integration.

\section{Relationships between supply chain digitalization, supply chain integration, and firm performance}

Digitalization in the supply chain could improve the efficiency of business processes through the use of electronic systems (e.g., ERP and EDI), including reduced production and transaction costs, improved inventory turnover, leaner logistic steps, automated manufacturing, and faster billing and payment settlement (Mukhopadhyay \& Kekre, 2002). Firms can increase their manufacturing throughput and quality, and minimize the number of breakdowns by making the manufacturing process more intelligent through the use of digital technologies and more and better data (Björkdahl, 2020). Furthermore, digitalization has the potential to boost the efficiency of product development and expedite product design by reducing the need for physical artifacts and prototypes (Björkdahl, 2020). In addition to the improvement of internal efficiency, digital transformation is capable of growing the firm by adding value for customers. Digitized systems and processes facilitate the customer journey in terms of providing efficient transactions and service delivery, which can satisfy the customers' increasing demand for personalized products (Gorbach, 2017). This phenomenon is exemplified in the case of Scania, one of the 26 case firms in Björkdahl (2020) study, the results of which have revealed that digitalization brings new business growth opportunities. A company is likely to reduce its cash conversion cycle with improved supply-side digitalization (Magretta, 1998), which directly influences the profitability of the firm, enhances its competitiveness, and creates its value (Lusch et al., 2010). In the existing literature, supply chain digitalization is largely believed to bring benefits to organizations. However, the academic investigation into how and why digitalization can create performance gains for firms in the context of 
the supply chain is limited (Björkdahl, 2020; Mukhopadhyay \& Kekre, 2002; Rai et al., 2006). Therefore, the following hypothesis is proposed:

H1: Supply chain digitalization has a positive influence on firm performance.

Moreover, various studies have indicated that digitalization in the supply chain could play a key role in building integration in the organization (Gautr, 2020; Mukhopadhyay \& Kekre, 2002). For example, in a field study on the logistic operations at the assembly centers of Chrysler Corporation, Srinivasan et al. (1994) have found that the adoption of electronic data interchange (EDI) brings substantial benefits by facilitating the integration of information into the supply chain process and sharply reducing shipment errors. Rai et al. (2006) have shown that the IT infrastructure through the application of ERP and CRM digital transformation tools enables supply chain process integration, which in turn yields sustained gains in firm performance. Gautr (2020) has further supported this contention, indicating that digital technologies are believed to enable the integration across the various functions of a firm (e.g., material management, planning, and scheduling) to ensure that teams move forward in unison toward common goals. These studies have suggested that the application of digital technologies facilitates supply chain integration for improved firm performance. Although the important role of digitalization in the supply chain integration process is quite certain, the empirical evidence is unclear. Therefore, the following hypothesis is posited:

H2: Supply chain digitalization has a positive influence on internal integration.

As concluded from the extant literature, supply chain integration could be unsuccessful in the absence of a high level of internal integration. Hence, internal integration within the supply chain integration is the focus of this study. Internal integration is the degree to which firms are capable of integrating and collaborating across traditional functional boundaries to improve customer service (Cespedes, 1996; Kahn \& Mentzer, 1996).

In internal integration, the idea that different functions within a firm should not act as functional silos but instead as part of an integrated process is recognized. By integrating activities across different functions, real-time inventory information, production schedule, and customer order status can be shared, which improves company performance by gaining a competitive advantage. Such integration should engender superior performance (Frohlich \& Westbrook, 2001; Gimenez, 2006). In the literature, general support exists in favor of the positive impact of supply chain integration on firm performance, but mixed findings exist in various studies (Flynn et al., 2010; Leuschner et al., 2013). For example, Jayaram and Xu (2013) have found no significant association between supplier integration and flexibility performance; Leuschner et al. (2013) have revealed the lack of a significant association between the overall supply chain integration and flexibility performance; and relational integration with supply chain partners has even shown a negative effect on supply chain performance in Som et al. (2019) study on manufacturing industries in Ghana. Although the incomplete and evolving conceptualization of supply chain integration 
might explain the inconsistent findings (Flynn et al., 2010), further research is necessary to make the statements generalizable (Leuschner et al., 2013). Therefore, the following hypothesis is proposed:

H3: Internal integration has a positive influence on firm performance.

\section{Mediating role of supply chain integration}

Integration is undoubtedly critical for a successful supply chain and optimal firm performance (Flynn et al., 2010; Som et al., 2019; Zhao et al., 2013); however, an understanding of the requisites for achieving integration is lacking (Sheu et al., 2006). Bowersox et al. (2005) have emphasized that digital transformation is inevitable for a firm to achieve genuine collaboration. As proposed in $\mathrm{H} 2$ and $\mathrm{H} 3$, digitalization is expected to have an influence on internal integration, and internal integration is expected to be associated with performance. Hence, the following hypothesis is proposed:

H4: Internal integration mediates the relationship between supply chain digitalization and firm performance.

\section{Moderating role of supply chain digitalization}

Digitalization involves the integration of digital technologies into inbound and outbound activities to increase the efficiency of a firm (Björkdahl, 2020; Björkdahl \& Holmén, 2019). Successful ERP system implementation facilitates the internal integration by streamlining the internal functions (Akyuz \& Rehan, 2009; Gupta $\&$ Kohli, 2006). The application of digital technologies enables the organization to integrate the internal process better, thereby improving firm performance (Chong \& Zhou, 2014). Therefore, the following hypothesis is posited:

H5: Supply chain digitalization moderates the relationship between internal integration and firm performance.

Accordingly, the proposed research model presented in Fig. 1 demonstrates the hypothesized relationships between supply chain digitalization, internal integration, and firm performance.

\section{Methods}

\section{Questionnaire design and measures}

The survey instrument was developed based on a comprehensive literature review to identify valid measures for related constructs and adapted existing scales for measurement. In particular, the survey instrument covered three sections: (1) 


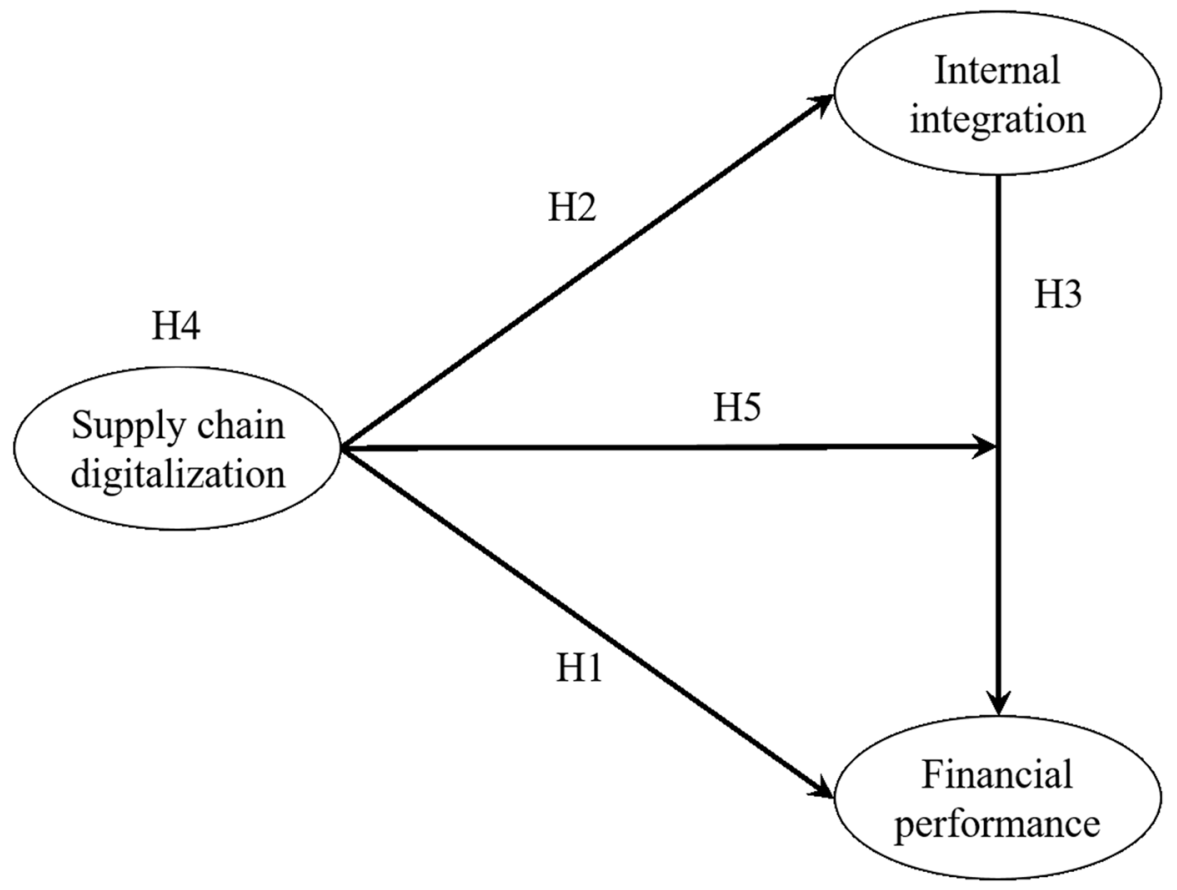

Fig. 1 Research model and hypotheses

supply chain digitalization, (2) internal integration, and (3) firm performance. First, the scale of supply chain digitalization (seven items) was adapted and modified from previous studies (Xue, 2014; Xue et al., 2013) to capture the extent to which firms implement supply chain management systems to electronically connect and conduct transactions internally and with their suppliers and customers in the supply chain. Second, internal integration (three items) was measured by a scale developed by Germain and Iyer (2006). Third, the scale of firm performance (four items) was obtained and modified from previous studies (Chan et al., 1997; Narasimhan \& Kim, 2002) to subjectively evaluate the overall firm performance compared to major industry competitors. All the indicators were measured using a 7-point Likert scale, from 1 = "strongly disagree" to 7 = "strongly agree."

As the scales drawn from the literature were in English, the back-translation approach Brislin (1970) was employed to translate the initial questionnaire developed in English into Chinese. The questionnaire items were carefully reviewed by a panel of both academic scholars and practitioners to verify the appropriateness of its contents and ensure its fitness for the purpose.

\section{Sampling and data collection}

The questionnaires were then distributed to practitioners in the logistics and supply chain industry in Mainland China for responses using an online survey platform, 
Wenjuanxing (www.wjx.cn). Wenjuanxing, a Chinese-based online survey company, functions similarly to Amazon Mechanical Turk and Qualtrics. Data were collected from its registered members, comprising more than 2.6 million people with diverse demographics (e.g., region, career, and industry). To ensure the validity and realistic reflection of surveys, Wenjuanxing provides a series of strict quality control mechanisms to remove the invalid answers via an automatic or manual inspection. Additionally, a setting can ensure that every IP address or Internet device has only one chance to answer the questionnaire.

In this study, samples were selected from nationwide members, and they were consistent with the demographic and geographic distribution of the Chinese population. One attention check question was included in the questionnaires to avoid inauthentic responses such as "fast clicks" (respondents who randomly or quickly clicked on an answer rather than carefully choosing one). A total of 264 completed questionnaires were collected. Data were carefully scrutinized for inauthentic responses. A profile of the respondents is presented in Table 1. Most of the respondents (79\%) have been in their position for more than 3 years; thus, they should be knowledgeable about the information requested.

\section{Data analysis and results}

Data analysis was performed by applying the partial least squares structural equation modeling (PLS-SEM) approach via SmartPLS 3.0 (Ringle et al., 2015). The PLS-SEM has been regarded as a useful technique for business-related studies in recent years (Chiu \& Cho, 2021; Cho et al., 2021; Hair et al., 2011). Prior to conducting PLS-SEM, data were scrutinized by the Mahalanobis distance approach to identify univariate and multivariate outliers (Hair et al., 2010). Out of the 264 valid responses, 27 univariate and multivariate outliers were identified and removed. As a result, 237 responses remained for further analysis. Following the guideline of Hair et al. (2017), data were analyzed and interpreted in two phases. First, the measurement model was employed by the PLS algorithm to assess internal consistency reliability, convergent validity, and discriminant validity. Second, the structural model was performed by PLS bootstrapping (5000 subsamples) to examine the hypotheses in this study.

\section{Common method bias}

The data were collected from a single survey, thus raising the possibility that the issue of common method bias might occur (Craighead et al., 2011; Podsakoff et al., 2003). Therefore, this issue needs to be examined prior to applying PLS-SEM (Hair et al., 2017; Kock, 2017). Following Kock's (2017) approach, a full collinearity test was used to scrutinize common method bias in PLS-SEM by examining variance inflation factors (VIF). VIF values that are higher than 3.3 indicate the problem of common method bias, which causes the inaccuracy of the structural model. Consequently, all the VIF values for all the items and constructs were found to be lower than 3.3 , signifying the absence of common method bias in this study. 
Table 1 Respondent characteristics $(N=264)$

\begin{tabular}{llc}
\hline Industry type & Sample & Percentage \\
Operations/manufacturing & 213 & $80.68 \%$ \\
Trader/wholesaler/distributor/retailer & 36 & $13.64 \%$ \\
Logistics or other service provider & 13 & $4.92 \%$ \\
$\quad$ Other & 2 & $0.76 \%$ \\
No. of employee in the firm & & \\
$<101$ & 36 & $13.64 \%$ \\
$101-500$ & 134 & $50.76 \%$ \\
$501-1000$ & 52 & $19.70 \%$ \\
$>1000$ & 46 & $17.42 \%$ \\
Annual sales revenue (RMB) & & \\
$<50 \mathrm{M}$ & 71 & $26.89 \%$ \\
50-100 M & 85 & $32.20 \%$ \\
100-500 M & 73 & $27.65 \%$ \\
$>500 \mathrm{M}$ & 35 & $13.26 \%$ \\
Position & & \\
Top management & 22 & $8.33 \%$ \\
Middle management & 95 & $35.98 \%$ \\
General staff & 147 & $55.68 \%$ \\
Years in current positions & & \\
$<3$ years & 56 & $21.21 \%$ \\
3-5 years & 89 & $33.71 \%$ \\
5-10 years & 94 & $35.61 \%$ \\
$>10$ years & 29 & $10.98 \%$ \\
\hline & &
\end{tabular}

\section{Measurement model assessment}

First, the internal consistency reliability of measurement was assessed by Cronbach's alpha and composite reliability (CR). The cut-off value for both Cronbach's alpha and CR is 0.70 (Hair et al., 2017). As reported in Table 2, CR values and Cronbach's alpha coefficients for all the constructs were higher than 0.70 , indicating adequate internal consistency reliability. Moreover, convergent validity was evaluated by considering factor loadings and average variance extracted (AVE). As shown in Table 2, all the factor loadings exceed the recommended value of 0.70, and AVE values are higher than the suggested value of 0.50 (Hair et al., 2017), supporting the convergent validity.

In addition, discriminant validity was evaluated by the criterion proposed by Fornell and Larcker (1981) and the heterotrait-monotrait ratio of correlations (HTMT) proposed by Henseler et al. (2015). According to Fornell and Larcker (1981), all the inter-correlations need to be lower than all the AVE square roots of each construct. Meanwhile, the HTMT scores of all the constructs need to be lower than the suggested criterion of 0.85 . As reported in Table 3, both the Fornell-Larcker criterion and the HTMT ratio fulfilled the requirements, therefore establishing the discriminant validity. 
Table 2 Summary of model measurement assessment

Constructs and items

Supply chain digitalization $(M=5.504, S D=.827, \alpha=.889, C R=.913, A V E=.600)$

SCD1: In general, your company always applies digital technologies within your own company

SCD2: Your company transacts with a high proportion of suppliers through digital technologies $\quad .735$

SCD3: Your company conducts high transactional volume with suppliers through digital technolo- $\quad .778$ gies

SCD4: In general, your company always applies digital technologies to transact with suppliers $\quad .806$

SCD5: Your company transacts with a high proportion of customers through digital technologies $\quad .801$

SCD6: Your company conducts high transactional volume with customers through digital tech- $\quad .755$ nologies

SCD7: In general, your company always applies digital technologies to transact with customers

Internal integrity $(M=5.360, S D=981, \alpha=.778, C R=.870, A V E=.691)$

II1: Interdepartmental committees, which are set up to allow departments to engage in decisionmaking on an ongoing basis

II2: Cross-functional teams, which are temporary bodies set up to facilitate interdepartmental collaboration on a specific project

II3: Liaison personnel whose specific job it is to coordinate the efforts of several departments for the purpose of a specific project

Firm performance $(M=5.120, S D=.919, \alpha=.878, C R=.916, A V E=.731)$

As compared to the major industry competitors, the performance of is better

FP1: Sales growth

FP2: Profit growth

FP3: Market share growth

FP4: Return on investment growth

$\lambda=$ factor loadings

\section{Structural model assessment}

The PLS algorithm was conducted to calculate path coefficients, and the PLS bootstrapping algorithm with the resampling of 5000 was employed to determine their significance level (0.05). First, the chi-square value $\left(R^{2}\right.$ value) was assessed to verify the explanatory power of exogenous variables on endogenous variables. As a result, the model explained $32.2 \%$ of the variance for internal integration and $23.8 \%$ of the variance for firm performance. As shown in Table 4, supply chain digitalization had a positive influence on firm performance $(\beta$ SCD FP $=0.322, t=4.740, p<0.001)$ and internal integration $(\beta$ SCD II $=0.549, t=10.089, p<0.001)$, supporting $\mathrm{H} 1$ and $\mathrm{H} 2$. Moreover, internal integration had a positive impact on firm performance $(\beta$ II FP $=0.230, t=2.981, p=0.003$ ), and $\mathrm{H} 3$ was supported.

Moreover, the mediating effect of internal integration on the relationship between supply chain digitalization and firm performance was explored by following the guidelines of Nitzl et al. (2016). The first step was to examine the significance of the indirect effect $(a \times b)$. If the indirect effect is significant, then mediation exists (Rucker et al., 2011; Zhao et al., 2010). The second step was to determine the type 
Table 3 Discriminant validity (Fornell and Larcker criterion and HTMT)

\begin{tabular}{llll}
\hline Fornell and Larcker criterion & & & \\
\hline Constructs & 1 & 2 & 3 \\
1.Supply chain digitalization &. $\mathbf{7 7 5}$ & & \\
2.Internal integration & .549 & $\mathbf{. 8 3 2}$ & \\
3.Firm performance & .448 & .407 & $\mathbf{. 8 5 5}$ \\
HTMT & & & \\
Constructs & 1 & 2 & 3 \\
1.Supply chain digitalization & & & \\
2.Internal integration & .652 & & \\
3.Firm performance & .499 & .480 & \\
\hline
\end{tabular}

Bold values are square root of AVE

of mediation by assessing the significance of the direct effect $\left(c^{\prime}\right)$ (Nitzl et al., 2016; Zhao et al., 2010). As reported in Table 4, the indirect effect was significant $\left(\beta_{\text {SCD II FP }}=0.126, t=2.939, p=0.003\right)$, and the direct relationship between supply chain digitalization and firm performance was significant. Hence, the partial mediation (complementary mediation) of internal integration in the research model occurs (Rucker et al., 2011; Zhao et al., 2010), thereby supporting H4.

In addition, the moderating effect of supply chain digitalization was analyzed in the relationship between internal integration and firm performance. To determine whether the moderator exerts a significant effect on the relationship, the PLS twostage approach was employed (Hair et al., 2017). First, the independent variable (internal integration) and moderator (supply chain digitalization) were multiplied to generate the interaction term (internal integration $\times$ supply chain digitalization) (Ramayah et al., 2018). This interaction term was subsequently used to evaluate its influence on firm performance. As shown in Table 4 and Fig. 2, supply chain digitalization positively moderated the relationship between internal integration and firm

Table 4 Summary results of hypothesized model testing

\begin{tabular}{llll}
\hline Hypotheses & $\begin{array}{l}\text { Standardized } \\
\text { coefficient }(\beta)\end{array}$ & $\begin{array}{l}\text { Standard } \\
\text { deviation }\end{array}$ & $t$-value \\
\hline Direct effect & & & \\
H1: SCD FP & .322 & .068 & $4.740 * * *$ \\
H2: SCD II & .549 & .054 & $10.089 * * *$ \\
H3: II FP & .230 & .077 & $2.981^{* *}$ \\
Indirect effect & & & \\
H4: SCD II FP & .126 & .043 & $2.939 * *$ \\
Moderating effect & & & \\
H5: II $\times$ SCD FP & .237 & .044 & $5.342 * * *$ \\
\hline
\end{tabular}

$S C D$ supply chain digitalization, $I I$ internal integration, $F P$ firm performance

${ }^{* * * *} p<.001, * * p<.01$ 
performance $\left(\beta_{\mathrm{II} \times \mathrm{SCD} F \mathrm{FP}}=0.237, t=5.342, p<0.001\right)$, supporting H5. In particular, supply chain digitalization strengthened the positive relationship between internal integration and firm performance.

\section{Discussion}

The primary objective of this study was to examine the relationships between supply chain digitalization, supply chain integration, and firm performance. Internal integration was adopted as the construct in this study due to its importance for supply chain integration. The conceptualized research model was established based on the extant literature. Five hypotheses were consequently established. Drawing from the empirical results, all five hypotheses were statistically supported and found to be significant. Digitalization has a positive influence on firm performance and internal integration. Internal integration has a positive influence on firm performance and a mediating effect on the relationship between supply chain digitalization and firm performance. More importantly, supply chain digitalization has a positive moderating effect on the relationship between internal integration and firm performance. The theoretical and practical implications are elaborated in the next sections.

\section{Theoretical implications}

The primary contribution of this study is the development of a research model to empirically examine the relationships between supply chain digitalization, internal integration, and firm performance. First, supply chain digitalization has shown a significant positive influence on firm performance $(\mathrm{H} 1)$. This result provides empirical

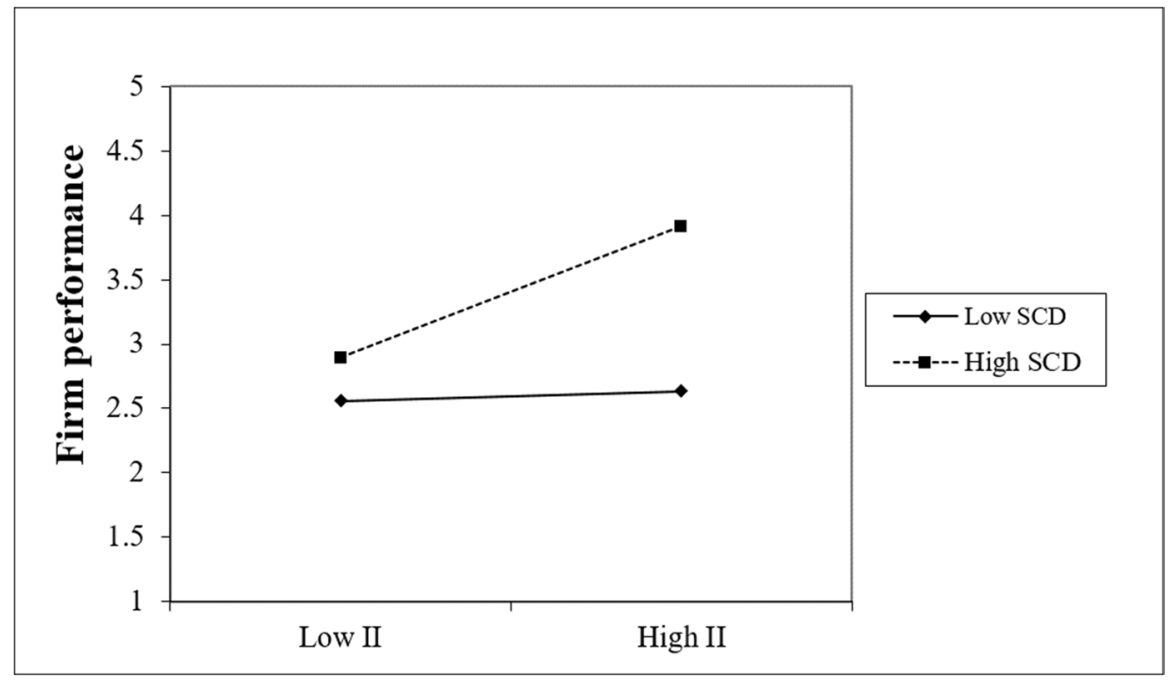

Fig. 2 The moderating effect of supply chain digitalization on the relationship between internal integration and firm performance. Note: $\mathrm{SCD}=$ supply chain digitalization, $\mathrm{II}=$ internal integration 
evidence to various previous views and studies: The firm is likely to reduce its cash conversion cycle with improved digitalization (Magretta, 1998); supply chain digitalization improves the efficiency of the business process (Mukhopadhyay \& Kekre, 2002); digitized systems and processes facilitate the customer journey and eventually boost customer satisfaction (Gorbach, 2017); and supply chain digitalization improves the quality of manufacturing processes (Björkdahl, 2020). These improvements by digitalization eventually enhance the competitiveness of the firm and create its value (Lusch et al., 2010).

Second, supply chain digitalization has a positive influence on internal integration (H2). This finding is consistent with previous studies (Akyuz \& Rehan, 2009; Chong \& Zhou, 2014) that digitalization transformation helps the firm to streamline the internal function for better internal integration (Mukhopadhyay \& Kekre, 2002; Rai et al., 2006); additionally, this result provides further evidence to Iddris (2018) argument that the application of digital technologies is highly associated with supply chain integration.

Third, internal integration has a positive influence on firm performance (H3), which adds evidence to the belief about the benefits of internal integration. This result is consistent with the previous studies (Gimenez, 2006; Jayaram \& Xu, 2013). More specifically, by integrating activities across different functions, firms perform better through the sharing of real-time inventory information, production schedule, and customer order status, among others. The integrative efforts between functional departments drive the competitive advantage of a firm (Stank et al., 1999).

Fourth, the significant mediating effect of internal integration is identified in the relationship between supply chain digitalization and firm performance (H4). More specifically, internal integration shows the partial mediating effect (i.e., complementary mediation) on the relationship between supply chain digitalization and firm performance as the direct path from supply chain digitalization to firm performance (Baron \& Kenny, 1986; Rucker et al., 2011; Zhao et al., 2010). This finding provides additional knowledge on the relationships between supply chain digitalization, internal integration, and firm performance, which indicates that, to a certain extent, supply chain digitalization offers firm performance that will undergo the path of internal integration. Moreover, this finding provides some empirical support to Bowersox et al.'s (2005) argument that for a firm to achieve true collaboration, it must undertake a digital business transformation.

Finally, supply chain digitalization has a positive moderating effect on the relationship between internal integration and firm performance (H5). This finding demonstrates that digitalization plays a decisive role in the internal integration process for enhanced firm performance. As shown in Fig. 2, the improvement in firm performance is quite limited with better internal integration when a low level of supply chain digitalization is observed (the slope is relatively flat, although a significant relationship is evident). However, the improvement in firm performance with better internal integration is significantly greater with a higher level of supply chain digitalization (the slope is steep). In other words, internal integration could only improve very little firm performance without a high level of supply chain digitalization. This result can provide additional insight to explain the mixed findings in some previous studies regarding the relationship between 
supply chain integration and firm performance (Flynn et al., 2010; Leuschner et al., 2013). The improvement by supply chain integration only on firm performance might not be noticeable without a high level of digitalization. In addition, it might provide a different view on Lyall et al.'s (2018) article, "The Death of Supply Chain Management," claiming that new digital technologies are entirely taking over supply chain function in the next 5-10 years. Based on the findings in this study, digitalization is indicated to play a decisive role in the supply chain integration process, and the firm's performance is subsequently restrained without a high level of digitalization.

In summary, the findings from $\mathrm{H} 1$ to $\mathrm{H} 3$ provide more empirical evidence to existing beliefs and support to previous studies. More importantly, regarding $\mathrm{H} 4$ and $\mathrm{H} 5$, the findings of this study fill the knowledge gap in understanding the relationships between digitalization, supply chain integration, and firm performance.

\section{Practical implications}

This study can address the struggle organizations are encountering in transforming the visionary ideas to a missionary level of a digital supply chain by providing evidence that higher level of supply chain digitization can drive a higher level of ethical supply chain in the perspective of supply chain visibility and efficiency in operations. The findings in this study can also clarify the practical concern raised in the Supply Chain Digitization Benchmark Survey in SupplyChainDigest (2016) that most of the companies are perceived to be highly unclear about what "digitizing" the supply chain signifies. Many firms are far from ready to benefit from digitalization (Björkdahl, 2020), although they understand their need to invest more in the digitalization transformation process. Without doing so, these firms are likely to be left behind and eventually go out of business (Saxena, 2016). However, low readiness might be explained by the challenge for both researchers and practitioners to leverage these technologies for improving company performance (Waller \& Fawcett, 2013, 2014).

Based on this study, the suggestion is that the investment of digital technologies should be more focused on the internal integration process of the supply chain. One of the examples is the extensive use of the ERP system (e.g., SAP S/4HANA, claiming a 5-year ROI of 547\%), which facilitates the integration of processes, data, and various functions in a company by unifying all the business processes from order processing to the distribution of physical products. ERP systems have the potential not only to boost the strength and success of a company but also to destroy the firm itself (Gupta \& Kohli, 2006). Thus, to obtain the maximal benefits, companies need to make sure that their ERP implementation can support the integration of the business processes across the organization, which is the key factor contributing to maximal benefits after the ERP implementation. Some companies consider the ERP implementation as an IT project, with the IT department driving the completion of the implementation. However, a successful ERP implementation does not signify that maximal benefits 
can be brought to the company, unless such implementation could be capable of internally aligning and integrating all the business processes. Therefore, it is suggested that the supply chain executives should lead the ERP implementation with support from the IT department to ensure that all the business processes are aligned. This view is significant as increasing number of multinational companies are adopting ERP solutions (e.g., SAP and Oracle), spending millions of dollars to improve their operational efficiency, when ERP implementation performance is believed to be highly associated with the level of internal integration (Hwang \& Grant, 2011).

Additionally, those digital technologies in the supply chain generally include BDA, advanced manufacturing technologies with sensors, decentralized agentdriven control, advanced robotics, augmented reality, advanced tracking and tracing technologies, and additive manufacturing/3D printing (Ivanov et al., 2019). The current study provides more evidence to executives that they are able to obtain benefits by adopting suitable digital technologies in the supply chain. For example, additive manufacturing/3D printing engenders the possibility of producing modules, components, and even end products in one place, and indeed in any place in the supply chain (Khajavi et al., 2014; Li et al., 2017). Although the present study is focused on internal integration, supply chain digitalization (e.g., CRM and SRM) should also be extended to external supply chain members such as customers and suppliers to reap greater benefits.

\section{Limitations and future studies}

This study has some limitations and opportunities for future research. First, the amount of sample data collected for this study was relatively small due to the difficulty in obtaining responses from organizations. Future studies could split data from different industries and compare the results between various industries. Moreover, the survey was conducted during the outbreak of the COVID-19 pandemic, which might have affected the responses of the participants. Future studies may consider the impact of the COVID-19 pandemic and explore its impact on the supply chain industry.

Availability of data and material The data presented in this study are available on request from the corresponding author.

\section{Declarations}

Ethics approval This study has been performed in accordance with the Declaration of Helsinki.

Consent to participate Informed consent was obtained from all subjects involved in the study.

Conflict of interest The authors declare no competing interests. 


\section{References}

Abdirad, M., \& Krishnan, K. (2020). Industry 4.0 in logistics and supply chain management: A systematic literature review. Engineering Management Journal, 1-15. https://doi.org/10.1080/10429247. 2020.1783935

Akyuz, G. A., \& Rehan, M. (2009). Requirements for forming an 'e-supply chain.' International Journal of Production Research, 47(12), 3265.

Baron, R. M., \& Kenny, D. A. (1986). The moderator-mediator variable distinction in social psychological research: Conceptual, strategic, and statistical considerations. Journal of Personality and Social Psychology, 51(6), 1173.

Björkdahl, J. (2020). Strategies for digitalization in manufacturing firms [Article]. California Management Review, 62(4), 17-36. https://doi.org/10.1177/0008125620920349

Björkdahl, J., \& Holmén, M. (2019). Exploiting the control revolution by means of digitalization: Value creation, value capture, and downstream movements. Industrial and Corporate Change, 28(3), 423-436.

Bowersox, D. J., Closs, D. J., \& Drayer, R. W. (2005). The digital transformation: Technology and beyond. Supply Chain Management Review, 9(1), 22-29.

Brislin, R. W. (1970). Back-translation for cross-cultural research. Journal of Cross-Cultural Psychology, 1(3), 185-216. https://doi.org/10.1177/135910457000100301

Büyüközkan, G., \& Göçer, F. (2018). Digital supply chain: Literature review and a proposed framework for future research [Article]. Computers in Industry, 97, 157-177. https://doi.org/10.1016/j.compi nd.2018.02.010

Cespedes, F. V. (1996). Beyond teamwork: How the wise can synchronize. Marketing Management, 5(1), 24.

Chan, Y. E., Huff, S. L., Barclay, D. W., \& Copeland, D. G. (1997). Business strategic orientation, information systems strategic orientation, and strategic alignment. Information Systems Research, 8(2), $125-150$.

Chiu, W., \& Cho, H. (2021). E-commerce brand: The effect of perceived brand leadership on consumers' satisfaction and repurchase intention on e-commerce websites. Asia Pacific Journal of Marketing and Logistics, 33(6), 1339-1362. https://doi.org/10.1108/APJML-10-2018-0403

Cho, H., Lee, H.-W., \& Chiu, W. (2021). Satellite fans: Does sport nostalgia influence purchase intention toward sponsors' products? Journal of Retailing and Consumer Services, 62, 102653. https://doi. org/10.1016/j.jretconser.2021.102653

Chong, A.Y.-L., \& Zhou, L. (2014). Demand chain management: Relationships between external antecedents, web-based integration and service innovation performance. International Journal of Production Economics, 154(August), 48-58.

Craighead, C. W., Ketchen, D. J., Dunn, K. S., \& Hult, G. T. M. (2011). Addressing common method variance: Guidelines for survey research on information technology, operations, and supply chain management. IEEE Transactions on Engineering Management, 58(3), 578-588.

DHL. (2018). Retrieved Accessed 4 February 2018. from https://resilience360.com/.

Erol, S., Schumacher, A., \& Sihn, W. (2016). Strategic guidance towards Industry 4.0 - A three-stage process model. International Conference on Competitive Manufacturing.

Errassafi, M., Abbar, H., \& Benabbou, Z. (2019). The mediating effect of internal integration on the relationship between supply chain integration and operational performance: Evidence from Moroccan manufacturing companies. Journal of Industrial Engineering and Management, 12(2), 254-273. https://doi.org/10.3926/jiem.2794

Flynn, B. B., Huo, B., \& Zhao, X. (2010). The impact of supply chain integration on performance: A contingency and configuration approach. Journal of Operations Management, 28(1), 58.

Fornell, C., \& Larcker, D. F. (1981). Evaluating structural equation models with unobservable variables and measurement error. Journal of Marketing Research, 18(1), 39-50. https://doi.org/10.2307/ 3151312

Frederico, G. F., Garza-Reyes, J. A., Anosike, A., \& Kumar, V. (2019). Supply Chain 4.0: Concepts, maturity and research agenda. Supply Chain Management: An International Journal, 25(2), 262282. https://doi.org/10.1108/scm-09-2018-0339

Frohlich, M. T., \& Westbrook, R. (2001). Arcs of integration: An international study of supply chain strategies. Journal of Operations Management, 19(2), 185-200. 
Gautr, R. (2020, 2020 Feb 29). Digitization in supply chain: Digital technologies in chemical industries: Supply chain. Chemical Industry Digest.

Germain, R., \& Iyer, K. (2006). The interaction of internal and downstream integration and its association with performance. Journal of Business Logistics, 27(2), 29-52.

Gimenez, C. (2006). Logistics integration processes in the food industry. International Journal of Physical Distribution \& Logistics Management, 36(3), 231-249. https://doi.org/10.1108/0960003061 0661813

Gorbach, G. (2017). The great digitization of industry. Supply Chain Managment Review, September/ October, 24-29.

Gupta, M., \& Kohli, A. (2006). Enterprise resource planning systems and its implications for operations function. Technovation, 26(5,6), 687-696.

Hair, J. F., Black, W. C., Babin, B. J., \& Anderson, R. E. (2010). Multivariate data analysis (7th ed.). Prentice-Hall.

Hair, J. F., Hult, G. T. M., Ringle, C., \& Sarstedt, M. (2017). A primer on partial least squares structural equation modeling (PLS-SEM) (2 ed.). Sage Publications.

Hair, J. F., Ringle, C. M., \& Sarstedt, M. (2011). PLS-SEM: Indeed a silver bullet. Journal of Marketing Theory and Practice, 19(2), 139-152. https://doi.org/10.2753/MTP1069-6679190202

Henseler, J., Ringle, C. M., \& Sarstedt, M. (2015). A new criterion for assessing discriminant validity in variance-based structural equation modeling. Journal of the Academy of Marketing Science, 43(1), 115-135. https://doi.org/10.1007/s11747-014-0403-8

Huo, B. F., Zhao, X. D., \& Lai, F. J. (2014). Supply chain quality integration: Antecedents and consequences. Ieee Transactions on Engineering Management, 61(1), 38-51. https://doi.org/10.1109/ Tem.2013.2278543

Hwang, Y., \& Grant, D. (2011). Understanding the influence of integration on ERP performance. Information Technology and Management, 12(3), 229-240. https://doi.org/10.1007/s10799-011-0096-3

Iddris, F. (2018). Digital supply chain: Survey of the literature. International Journal of Business Research and Management, 9(1), 47-61. http://urn.kb.se/resolve?urn=urn:nbn:se:hh:diva-37526. Accessed June-Aug 2021.

Ivanov, D., Dolgui, A., \& Sokolov, B. (2019). The impact of digital technology and Industry 4.0 on the ripple effect and supply chain risk analytics. International Journal of Production Research, 57(3), 829-846. https://doi.org/10.1080/00207543.2018.1488086

Jayaram, J., \& Xu, K. (2013). The relative influence of external versus internal integration on plant performance in China. International Journal of Production Economics, 146(1), 59.

Kahn, K. B., \& Mentzer, J. T. (1996). Logistics and interdepartmental integration. International Journal of Physical Distribution \& Logistics Management, 26(8), 6 - 14. http://www.emeraldinsight. com/https://doi.org/10.1108/09600039610182753

Khajavi, S. H., Partanen, J., \& Holmström, J. (2014). Additive manufacturing in the spare parts supply chain. Computers in Industry, 65(1), 50.

Kock, N. (2017). Common method bias: A full collinearity assessment method for PLS-SEM. In H. Latan \& R. Noonan (Eds.), Partial least squares path modeling: Basic concepts, methodological issues and applications (pp. 245-257). Springer International Publishing. https://doi.org/10.1007/978-3319-64069-3_11

Kolberg, D., Knobloch, J., \& Zühlke, D. (2017). Towards a lean automation interface for workstations. International Journal of Production Research, 55(10), 2845-2856. https://doi.org/10.1080/00207 543.2016.1223384

Legner, C., Eymann, T., Hess, T., Matt, C., Böhmann, T., Drews, P., Mädche, A., Urbach, N., \& Ahlemann, F. (2017). Digitalization: Opportunity and challenge for the business and information systems engineering community. Business \& Information Systems Engineering, 59(4), 301-308. https://doi. org/10.1007/s12599-017-0484-2

Leuschner, R., Rogers, D. S., \& Charvet, F. F. (2013). A meta-analysis of supply chain integration and firm performance. Journal of Supply Chain Management, 49(2), 34-57.

Li, Y., Jia, G., Cheng, Y., \& Hu, Y. (2017). Additive manufacturing technology in spare parts supply chain: A comparative study. International Journal of Production Research, 55(5), 1498-1515. https://doi.org/10.1080/00207543.2016.1231433

Lusch, R. F., Vargo, S. L., \& Tanniru, M. (2010). Service, value networks and learning. Journal of the Academy of Marketing Science, 38(1), 19-31. https://doi.org/10.1007/s11747-008-0131-z 
Luthra, S., \& Mangla, S. K. (2018). Evaluating challenges to Industry 4.0 initiatives for supply chain sustainability in emerging economies. Process Safety and Environmental Protection, 117, 168179. https://doi.org/10.1016/j.psep.2018.04.018

Lyall, A., Mercier, P., \& Gstettner, S. (2018). The death of supply chain management [Article]. Harvard Business Review Digital Articles, 2-4.

Magretta, J. (1998). The power of virtual integration: An interview with Dell Computer's Michael Dell. Harvard Business Review, 76(2), 72-84.

Manaadiar, H. (2020). How to achieve cost saving through digitalization in shipping.

Min, S., Zacharia, Z. G., \& Smith, C. D. (2019). Defining supply chain management: In the past, present, and future. Journal of Business Logistics, 40(1), 44-55. https://doi.org/10.1111/jbl.12201

Mukhopadhyay, T., \& Kekre, S. (2002). Strategic and operational benefits of electronic integration in B2B procurement processes. Management Science, 48(10), 1301-1313.

Narasimhan, R., \& Kim, S. W. (2002). Effect of supply chain integration on the relationship between diversification and performance: Evidence from Japanese and Korean firms. Journal of Operations Management, 20(3), 303-323. https://doi.org/10.1016/S0272-6963(02)00008-6

NASDAQ. (2020, 15 Sep). Digitization in logistic supply chain market forecast to 2027. https:// search-proquest-com.ezproxy.lib.ouhk.edu.hk/docview/2442638791 ?accountid=16720. Accessed June-Aug 2021.

Nitzl, C., Roldan Jose, L., \& Cepeda, G. (2016). Mediation analysis in partial least squares path modeling: Helping researchers discuss more sophisticated models. Industrial Management \& Data Systems, 116(9), 1849-1864. https://doi.org/10.1108/IMDS-07-2015-0302

Podsakoff, P. M., MacKenzie, S. B., Lee, J.-Y., \& Podsakoff, N. P. (2003). Common method biases in behavioral research: A critical review of the literature and recommended remedies. Journal of Applied Psychology, 88(5), 879-903. https://doi.org/10.1037/0021-9010.88.5.879

Queiroz Maciel, M., Pereira Susana Carla, F., Telles, R., \& Machado Marcio, C. (2019). Industry 4.0 and digital supply chain capabilities: A framework for understanding digitalisation challenges and opportunities. Benchmarking: An International Journal, ahead-of-print. https://doi.org/10. 1108/bij-12-2018-0435

Rai, A., Patnayakuni, R., \& Nainika, S. (2006). Firm performance impacts of digitally enabled supply chain integration capabilities. MIS Quarterly, 30(2), 225-246.

Ramayah, T., Hwa, C., Chuah, F., Ting, H., \& Memon, M. (2018). PLS-SEM using SmartPLS 3.0: Chapter 13: Assessment of moderation analysis. In T. Ramayah, J. Cheah, F. Chuah, H. Ting, \& M. A. Memon (Eds.), Partial least squares structural equation modeling (PLS-SEM) using SmartPLS 3.0: An updated guide and practical guide to statistical analysis. Pearson.

Ringle, C. M., Wende, S., \& Becker, J. M. (2015). SmartPLS 3. In SmartPLS GmbH. http://www. smartpls.com. Accessed June-Aug 2021.

Rucker, D. D., Preacher, K. J., Tormala, Z. L., \& Petty, R. E. (2011). Mediation analysis in social psychology: Current practices and new recommendations [Article]. Social \& Personality Psychology Compass, 5(6), 359-371. https://doi.org/10.1111/j.1751-9004.2011.00355.x

Sanders, N., \& Swink, M. (2020). Digital supply chain transformation: Visualizing the possibilities. Logistics Management (2002), 59(3), 42-48,50-53.

Saxena, P. (2016). Technology trends for the digital supply chain. Manufacturing Business Technology.

Sheu, C., HsiuJu Rebecca, Y., \& Chae, B. (2006). Determinants of supplier-retailer collaboration: evidence from an international study. International Journal of Operations \& Production Management, 26(1), 24 - 49. http://www.emeraldinsight.com/https://doi.org/10.1108/014435706106370 03

Som, J. O., Cobblah, C., \& Anyigba, H. (2019). The effect of supply chain integration on supply chain performance [Article]. IUP Journal of Supply Chain Management, 16(4), 7-38. https://search. ebscohost.com/login.aspx?direct $=$ true $\& \mathrm{db}=$ buh $\& A N=140446503 \&$ site $=$ ehost-live. $\quad$ Accessed June-Aug 2021.

Srinivasan, K., Kekre, S., \& Mukhopadhyay, T. (1994). Impact of electronic data interchange technology on JIT shipments. Management Science, 40(10), 1291.

Stank, T. P., Daugherty, P. J., \& Ellinger, A. E. (1999). Marketing/logistics integration and firm performance. International Journal of Logistics Management, 10(1), 11-24. https://doi.org/10.1108/ 09574099910805905 
Stock, G. N., Greis, N. P., \& Kasarda, J. D. (1998). Logistics, strategy and structure A conceptual framework: [1]. International Journal of Operations \& Production Management, 18(1), 37. https://doi. org/10.1108/01443579810192772

SupplyChainDigest. (2016). SCDigest Supply Chain Digitization Benchmark Survey. http://www.scdig est.com/assets/reps/Supply_Chain_Digitization_2016_Survey_Data.pdf. Accessed June-Aug 2021.

Swink, M., \& Nair, A. (2007). Capturing the competitive advantages of AMT: Design-manufacturing integration as a complementary asset. Journal of Operations Management, 25(3), 736.

Swink, M., \& Song, M. (2007). Effects of marketing-manufacturing integration on new product development time and competitive advantage. Journal of Operations Management, 25(1), 203. https:// search.proquest.com/scholarly-journals/effects-marketing-manufacturing-integration-on/docview/ 219548157/se-2?accountid=16720. Accessed June-Aug 2021.

UPS. (2018). Retrieved Accessed 11 February 2018. from https://www.youtube.com/watch?v=aYoNd 2nQqLg. Accessed June-Aug 2021.

Waller, M. A., \& Fawcett, S. E. (2013). Data science, predictive analytics, and big data: A revolution that will transform supply chain design and management. Journal of Business Logistics, 34(2), 77-84. https://doi.org/10.1111/jbl.12010

Waller, M. A., \& Fawcett, S. E. (2014). Click here to print a maker movement supply chain: How invention and entrepreneurship will disrupt supply chain design. Journal of Business Logistics, 35(2), 99-102. https://doi.org/10.1111/jbl.12045

Xue, L. (2014). Governance-knowledge fit and strategic risk taking in supply chain digitization. Decision Support Systems, 62, 54.

Xue, L., Zhang, C., Ling, H., \& Zhao, X. (2013). Risk mitigation in supply chain digitization: System modularity and information technology governance: JMIS. Journal of Management Information Systems, 30(1), 325.

Zhao, L., Huo, B., Sun, L., \& Zhao, X. (2013). The impact of supply chain risk on supply chain integration and company performance: A global investigation. Supply Chain Management, 18(2), 115-131. https://doi.org/10.1108/13598541311318773

Zhao, X., Huo, B., Selen, W., \& Yeung, J. H. Y. (2011). The impact of internal integration and relationship commitment on external integration. Journal of Operations Management, 29(1/2), 17.

Zhao, X., Lynch, J. G., Jr., \& Chen, Q. (2010). Reconsidering Baron and Kenny: Myths and truths about mediation analysis. Journal of Consumer Research, 37(2), 197-206. https://doi.org/10.1086/651257

Publisher's note Springer Nature remains neutral with regard to jurisdictional claims in published maps and institutional affiliations. 